\title{
HOW USEFUL IS THE GOLDEN TRIANGLE LAW IN ECONOMICS?
}

\author{
Marinko ŠKARE \\ Department of Economics and Tourism "Dr. Mijo Mirkovic", Juraj Dobrila University of Pula, \\ Preradovićeva 1/1, 52100 Pula, Croatia
}

Received 12 October 2012; accepted 02 January 2014

\begin{abstract}
We explore the long term relationship between unemployment, inflation and output in the United Kingdom during 1851-2011 in search for a possible "golden triangle" connecting "natural" unemployment, price stability and strong (fast) rates of output growth. Exploring the possibility of existence of such internal macroeconomic equilibrium is important in setting and attaining these most acclaimed macroeconomic objectives. Not only could the results be applied in setting policy objectives but also unveil if low unemployment, stable prices and fast growth are supportive objectives. Preliminary results are encouraging and open the path for further research on the subject. Not a single economic policy designed on just a vague notion on the relationship between inflation, unemployment and output should be used since it will bring disaster to the economy.
\end{abstract}

Keywords: economic growth, golden triangle, inflation, unemployment, Phillips curve.

Reference to this paper should be made as follows: Škare, M. 2014. How useful is the golden triangle law in economics?, Technological and Economic Development of Economy 20(1): 133-153.

JEL Classification: O40, E31, E6, E24.

\section{Introduction}

Consistent and equilibrium dynamics between unemployment, prices and output in turn determines the state of the economy path or in A. W. Phillips' (1962) words "the course of economic affairs". Our perspective is in the tradition of Phillips' view on quantitative relations between employment, inflation and growth.

"Consideration of the average level of employment brings us to the question of the relations between employment, or unemployment, and inflation and the rate of growth".

Corresponding E-mail:

mskare@efpu.hr 
Large body of literature on unemployment, inflation and growth phenomena is present in economic discipline. That is strong evidence on why it is important to study the nature of these phenomena in economics. Studies researching phenomena in question were mainly looking for a bivariate relationship between the phenomena losing sight on a possible simultaneous relationship among all three phenomena in question. The same point was put forward by Phillips (1962) in his article. Having this in mind, this paper addresses exactly the issue of possible long run relationship existing between inflation, unemployment and output. For this purpose, UK economy was selected because of historical long time series availability. Study results presented in this paper show that better forecasting of macroeconomic indicators can be obtained if micro and macroeconomic indicators are grouped under three main economic forces - inflation, unemployment and output. Equilibrium relationship between these three economic forces determine past and future economy path. Policy makers not having knowledge on the equilibrium relationship between them cannot achieve steady state (internal equilibrium) in the economy. Design of efficient policy measure is virtually impossible since policy makers do not know what relationship holds between economic policy targets - prices, employment and output. Since close relationship between the targets of planned policy actions is unknown, it is not realistic that instruments of the same policy (inflation, unemployment and growth) will have positive effect on the economy. Quite contrary, results presented in this paper show policy makers would cause less damage to the economy when not interfering in the economy rather than using vague economic policies designed in the absence of information on quantitative relationships between the objectives of economic policy.

The structure of the paper is as follows. Section 1 shows the importance of the subject under investigation. Body of literature presenting evidence on the importance of the topic researched in this study is presented in the Section 2. Data and methodological framework is set up in the Section 3. Empirical results validating the hypothesis of inefficient policy actions in the presence of vague knowledge on relationship that holds between inflation, unemployment and output are shown in Section 4. The final section offers concluding remarks and research implications for policy practitioners and the field of economics.

\section{Related literature}

A vast number of studies have been carried out studying the relationship between unemployment and gross domestic product, unemployment and inflation ${ }^{1}$ (Philips' curve). Arthur M. Okun (1981) examines the nature of the relationship between inflation, unemployment and output stressing policymakers are faced with the inflation-unemployment tradeoff issue followed by the output-money nature of monetary phenomena. Macroeconomic measurements and forecasts have a large influence on the economy but lack in efficiency,

See Phelps (1967), Gordon (1990), Phelps and Zoega (1998), Nickell (1998), Lorenzoni (2010), Acemoglu and Scott (1994), Adams and Coe (1989), Aguiar and Manuel (2005), Altig et al. (1997), Apergis and Rezitis (2003), Attfield and Silverstone (1998), Bodman (1998), Brunner (1997), Campbell and Fisher (2000), Campbell and Mankiw (1987), Cochrane (1988), Courtney (1991), Cuaresma (2003), Davenport (1982), Evans (1989a, b), Keynes (1936), Lee (2000), Okun (1980), Palley (1993), Rothman (1991), Samuelson (2008), Sögner and Stiassny (2002), Thirlwall (1969), Thurow and Taylor (1966), Virén (2001), Weber (1995). 
accuracy and bias whenever economic shocks are present (Bratu 2012). Macroeconomic variables in turn affect financial markets leading to a domino effect by transferring risks and uncertainty between the two (Hsing 2011). Quantitative relations but also the effects of lag appears to be largely important both for fiscal and monetary policy (Jovanovski, Murić 2011). Fiscal sustainability although important for small open economies (Stubelj, Dolenc 2010) is subject to the law of the golden triangle. Kaldor (1992) noticed: "Policymakers are confronted with a trade-off between inflation and unemployment characterized by a traditional Philips curve. Price stability requires lower output, and high levels of output and employment entail inflation. Society can achieve more output if, but only if, it is prepared to accept a higher rate of inflation. By their influence on the level and growth of nominal income, the fiscal-monetary authorities determine the inflation rate. In that sense, inflation is always a monetary (or, more accurately, a monetary-fiscal) phenomenon. The growth of nominal income also determines the output of customer goods, and so output and employment are equally monetary phenomena”.

The trade-off issue was exposed by James Tobin (1996): “The output/price or unemployment/inflation trade-off is inexorable, that is to say, it can't be eliminated or mitigated by altering the fiscal/monetary policy mix. Another way to put the point is this: A certain volume of aggregate demand will place the economy at a certain point on the aggregate supply (AS) curve relating output to price level or on the short-run Phillips curve relating unemployment to inflation".

Kaldor (1992) observed unemployment as labour productivity related issue associated to the unemployment-output relationship linked to the price level through the wage levels: "When unemployment is general it must be the result of either a reduction in the marginal productivity of labour relatively to other factors or an increase in the cost of labour; and whatever the cause, the remedy will always involve either an increase in marginal productivity or reduction in labour cost".

Phillips theory was strongly criticized by Phelps (1967) and Friedman (1968) disputing observed unemployment-inflation empirical relation and inferred connotations for policy makers and monetary policy regulators.

There is wide agreement about the major goals of economic policy: high employment, stable prices (Hooker 2002; Nakon, Pescatori 2010) and rapid growth (Thirlwall, Norman 1970). There is less agreement that these goals are mutually compatible, or, among those who regard them as incompatible, about the terms at which they can and should be substituted for one another. There is least agreement about the role that various instruments of policy can and should play in achieving the several goals.

Song et al. (2012) show the importance of economic growth convergence theory for large economies as China.

\section{Data and methodology}

Long-term relationship between inflation, unemployment and output in United Kingdom over the period 1851-2011 is examined in this study. Long time series data lacking in robust data on unemployment for such a long time period limited the analysis. Time series data for 
unemployment were derived following Boyer and Hatton (2001), Reno (2010) as well as data from (Mitchell 1988), Hicks and Grahame (1999). Time series data on output and price level were obtained from Measuring Worth (2012) database.

Because of the observable stationarity in the data (after proven implementing unit root and cointegration tests) we use standard VAR and SVAR approach to examine potential long run link between prices, unemployment and growth in the United Kingdom. Following analysis results, long run equilibrium path between prices, unemployment and output was investigated. We estimate the UK potential output with the standard Hodrick-Prescott filter (1997) model. With the data collected, long term equilibrium model for inflation, unemployment and output for United Kingdom was set.

\section{A. Equilibrium assumptions}

Following procedure from (Škare 2010) optimal GDP, inflation and unemployment rates for the United Kingdom were obtained.

With the three golden nodes for the UK economy identified, a golden triangle model can be fully set and developed approach used in devising and implementing appropriate economic policy. To calculate the output gap series over the sample period standard HP filter was used:

$$
\sum_{i=1}^{T}\left(y_{t}-s_{t}\right)^{2}+\lambda \sum_{t=2}^{T-1}\left(\left(s_{t+1}-s_{t}\right)-\left(s_{t}-s_{t-1}\right)\right)^{2} .
$$

\section{B. Inflation, unemployment, output in the United Kingdom (1851-2011): a VAR model}

In this section we examine the dynamic effects between inflation, unemployment and output in a VAR framework. To identify long run relationship between unemployment, inflation and output in UK we use a stationary, stable VAR(3) process of the form:

$$
y_{t}=v+A_{1} y_{t-1}+\ldots+A_{p} y_{t-p}+B D_{t}+u_{t} .
$$

In order to test whether inflation, unemployment and output are jointly determined (and their behaviour) we use a VAR system with three variables or a three dimensional VAR(p):

$$
\left[\begin{array}{l}
\text { Inflat } \\
\text { Unem } \\
\text { Output }
\end{array}\right]=\left[\begin{array}{l}
\alpha_{z z} \alpha_{z y} \alpha_{z x} \\
\alpha_{y z} \alpha_{y y} \alpha_{y x} \\
\alpha_{x z} \alpha_{x y} \alpha_{x x}
\end{array}\right]\left[\begin{array}{l}
\text { Inflat }_{t-1} \\
\text { Unem }_{t-1} \\
\text { Output }_{t-1}
\end{array}\right]+\left[\begin{array}{l}
u_{z, t} \\
u_{y, t} \\
u_{x, t}
\end{array}\right],
$$

where: Inflat (Inf) = inflation rates in the United Kingdom 1851-2011; Unem (Unm) = unemployment rates in the United Kingdom 1851-2011; Output (Out) = output growth rates in the United Kingdom 1851-2011.

To check the stability of the process in (2) we use:

$$
\begin{aligned}
& \alpha^{n}-a_{1} \alpha^{n-1}-a_{2} \alpha^{n-2} \ldots a_{n}=0 \\
& \sum_{i=1}^{n}\left|a_{i}\right|<1
\end{aligned}
$$


and

$$
\begin{aligned}
& \operatorname{det}\left(I_{K}-A_{1} z-\ldots A_{p} z^{p}\right) \neq 0 \\
& \text { for }|z| \leq 1 .
\end{aligned}
$$

The roots of the polynomial are $>1$ in absolute values $(|z|=1.0262 / 1.2662 / 1.7801 / 1.7801 /$ $1.8200 / 1.8200 / 2.1537 / 2.1537 / 3.1464)$. To confirm the stationarity of the data and the stability of the VAR model standard unit roots (Dickey-Fuller, Phillips-Perron, GLS-detrended Dickey-Fuller, Kwiatkowski, Phillips, Schmidt, and Shin, Elliott, Rothenberg, and Stock Point Optimal and $\mathrm{Ng}$ and Perron) tests were performed. All tests show stationarity of the data in levels and strong rejections of the unit root presence in the series. Additional tests based on the group series rather than individual series, i.e. panel data unit roots test (Levin et al. 2002; Breitung 2000; Im et al. 2003), Fisher-type tests using ADF and PP tests (Maddala, Wu 1999; Choi 2001; Hadri 2000) also confirms the stability (stationarity) of the VAR process.

\section{Lag selection criteria (VAR(p) Order)}

Before we continue with the VAR modelling and before testing for the causality relations between inflation, unemployment and output we proceed with the VAR(p) order, i.e. optimal lag length selection. Following Akaike $(1969,1971)$ VAR order selection criteria's and procedures (Lütkepohl 2007) we estimate appropriate lag length as in:

$$
\begin{gathered}
F P E(m)=\operatorname{det}\left[\frac{T+K m+1}{T} \frac{T}{T-K m-1} \tilde{\sum}_{u}(m)\right]= \\
{\left[\frac{T+K m+1}{T-K m-1}\right]^{K} \operatorname{det} \tilde{\sum}_{u}(m) ;} \\
A I C(m)=\ln \left|\tilde{\sum}_{u}(m)\right|+\frac{2}{T}=\ln \left|\tilde{\sum}_{u}(m)\right|+\frac{2 m K^{2}}{T} ; \\
S C(m)=\ln \left|\tilde{\sum}_{u}(m)\right|+\frac{\ln T}{T}=\ln \left|\tilde{\sum}_{u}(m)\right|+\frac{\ln T}{T} m K^{2} ; \\
L R=(T-m)\left(\ln \left|\Sigma_{r}\right|-\ln \left|\Sigma_{u}\right|\right) \sim \chi^{2}(q) .
\end{gathered}
$$

HC and HQ support VAR(1) order, suggesting one lag length, FPE, AIC and LR supports the $\operatorname{VAR}(3)$ order with $\mathrm{p}=3$. Starting from the theoretical and also logical assumption that with a one lag length rigidity in the data (especially for unemployment and inflation should be expected) we choose the VAR(3) order for our VAR model as suggested from the tests results. Using VAR lag exclusion Wald test we check lag length for the model once more since appropriate lag length selection is crucial for our VAR model. Lag exclusion Wald test support the results of the selection criteria above (joint lags for the VAR model is 3) suggesting no exclusion in the second and third lag in the VAR model. Following Ho and Sorensen (1996) recommendation on the criteria to use we decide to go with VAR(3) model. 
The VAR order chosen was also scrutinized by the Granger causality relation with causality link strongly depending on the lag length pointing to the weak causality between inflation and unemployment in the first lag (as theoretically expected) contrary to the much stronger causality in the third lag. Post-estimation VAR order test also validated the lag length of (3) that we choose for the VAR model.

\section{Testing for causality}

We use pairwise Granger causality test to find out the nature of causality between inflation, unemployment and output in the United Kingdom for the period 1851-2011. Condition of Granger causality is defined as (Vercelli 2005):

(...) $Y_{n}$ is a cause of $X_{n+1}$ if

$$
F\left(X_{n+1} / \Omega_{n}\right) \neq F\left(X_{n+1} / \Omega_{n}-Y_{n}\right)
$$

In other words, the stochastic variable $Y_{n}$ Granger-causes the stochastic variable $X_{n+1}$ when the past and present values of $Y_{n}$ have "some unique information about what value $X_{n+1}$ will take in the immediate future" (Granger, Joyeux 1980).

Bierens (2007) Granger causality condition form as: (...) $Y_{t}$ does not Granger-cause $x_{t}$ if

$$
E\left[x_{t}-E\left(x_{t} \mid x_{t-1}, y_{t-1}, x_{t-2}, y_{t-2}, \ldots . .\right]^{2}=E\left[x_{t}-E\left(x_{t} \mid x_{t-1}, x_{t-2}, \ldots . .\right]^{2} .\right.\right.
$$

If $y_{t}$ Granger-causes $x_{t}$ then one can predict $x_{t}$ better using the whole past of the $x_{t}$ and $y_{t}$ processes then using only the past of $x_{t}$ :

$$
E\left[x_{t}-E\left(x_{t} \mid x_{t-1}, y_{t-1}, x_{t-2}, y_{t-2}, \ldots . .\right]^{2}<E\left[x_{t}-E\left(x_{t} \mid x_{t-1}, x_{t-2}, \ldots . .\right]^{2} .\right.\right.
$$

Pairwise Granger causality test (Block Exogenity Wald Test) results infer a one way causality between output and inflation (inflation does not Granger-cause output). Bidirectional (bilateral) causality between inflation and unemployment show strong evidence in favour of the Phillips curve hypothesis. For inflation and unemployment causality runs from inflation to unemployment and unemployment to inflation (both hypotheses are strongly accepted at $5 \%$ significance level). Hypothesis that change in unemployment influence (Granger cause) output growth dynamics is accepted both with the hypothesis that output growth Granger cause changes in unemployment (two-way causality between output growth and unemployment). Results presented in the table for the Granger causality test for the series provide solid evidence of Granger causality running (one-way between inflation and output), bilateral causality between inflation/unemployment and two-way causality between output/ unemployment in the United Kingdom during the sample period.

To check the causality between output, inflation and unemployment we use the standard F-test for the parameter restrictions and a Wald test for Granger causality (Table 1); causality of inflation for output:

$$
H_{0}: \alpha_{12, i}=0, i=1, \ldots . ., p,
$$


causality of unemployment for output:

$$
H_{0}: \alpha_{13, i}=0, i=1, \ldots . ., p .
$$

Following (9) and (10) we set up a model to test for Granger causality of the form:

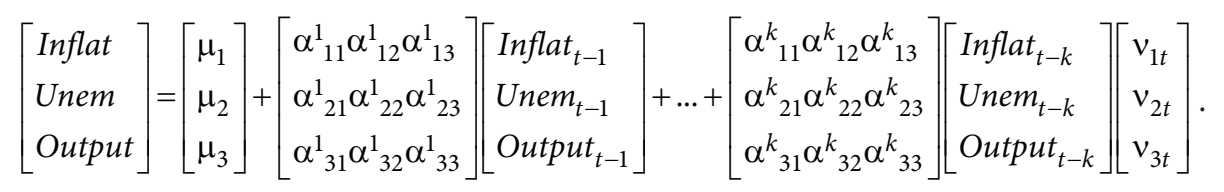

We also test for the instantaneous causality between output, inflation and unemployment following the null:

$$
H_{0}: E\left(u_{1, t} u_{2 t}^{\prime}\right)=0
$$

The null hypothesis of no instantaneous causality between unemployment/output $\left(y_{2}, y_{3}\right)$ to inflation $\left(y_{1}\right)$ :

$$
H_{0}: \alpha_{12,1}=\alpha_{13,1}=\alpha_{12,2}=\alpha_{13,2}=\alpha_{12,3}=\alpha_{13,3}=0,
$$

is strongly rejected inferring instantaneous causality between unemployment/output and inflation in the United Kingdom. Testing no instantaneous causality for inflation/unemployment and output:

$$
H_{0}: \alpha_{11,1}=\alpha_{12,1}=\alpha_{11,2}=\alpha_{12,2}=\alpha_{11,3}=\alpha_{12,3}=0,
$$

is also rejected at $1 \%$ level validating instantaneous causality between unemployment/output and inflation. Instantaneous non-causality between inflation/output and unemployment:

$$
H_{0}: \alpha_{11,1}=\alpha_{13,1}=\alpha_{11,2}=\alpha_{13,2}=\alpha_{11,3}=\alpha_{13,3}=0
$$

is also rejected at $1 \%$ level confirming instantaneous causality relations between all variables in the VAR(3) model we set. Although causality does not necessarily involve causality in strong sense of the word, finding causality in both directions (bilateral causality) between inflation, unemployment and output is encouraging for our hypothesis of quantitative relations existence among the three economic variables in short and long run.

\section{E. Estimated VAR(3) diagnostics and model adequacy (robustness)}

In this section we test our VAR(3) model for consistency and robustness with standard tests applying (residual autocorrelation, nonormality, conditional heteroskedasticity). Using aforementioned statistical tools we check the VAR(3) model underlying the data generation process for the time series variables of inflation, unemployment and output. 
1. Analysis of residuals

To check the model consistency we first graph standardized residuals, residual autocorrelations and cross correlations. We can see that properties of the residuals of the estimated VAR(3) model suggest no normality or ARCH problem in the model. After the descriptive analysis of the residuals we check the model for the residual autocorrelation with the Portmanteau (Lütkepohl 2007):

$$
H_{0}: R_{h}=\left(R_{1}, \ldots, R_{h}\right)=0
$$

and Breusch (1979) - Godfrey (1978) LM test:

$$
H_{0}: D_{1}=\ldots=D_{h}=0 .
$$

Tests show that null hypothesis of no serial autocorrelation in residuals can not be rejected validating the descriptive results above.

\section{Checking nonnormality in the $\operatorname{VAR}(3)$ model}

Nonnormality test (Cholesky, Doornik-Hansen, Urzua, Jarque-Bera) results of the VAR(3) model show no incidence of nonnormal residuals in the model (checking the normality of the white noise process). Results of the nonnormality tests proves that our stationary, stable $\operatorname{VAR}(3)$ process is normally distributed.

\section{ARCH-LM test for conditional heteroscedasticity}

Fitting a multivariate $\operatorname{ARCH}(q)$ model to the estimation of the residuals from the $\operatorname{VAR}(3)$ model we test the null of no conditional heteroscedasticity in the residuals:

$$
\begin{aligned}
& H_{0}: \beta_{1}=. .=\beta_{q}=0 \text { no conditional heteroscedasticity } \\
& H_{1}: \beta_{1} \neq 0 \text { or } \beta_{q} \neq 0, \ldots .
\end{aligned}
$$

Results of the ARCH-LM test show that the null is not rejected and there are no ARCH effects in the residuals.

\section{Stability analysis of the VAR model}

Estimated VAR(3) parameter constancy over the sample period and inferred stability of the estimated model is checked with CHOW and CUSUM tests, eigenvalues position over the unit circle recursive estimates and recursive residuals plotted.

Recursive estimates do not indicate parameter instability in the estimated VAR(3) model. All parameter estimates lies in the $95 \%$ confidence interval. Stability is also proven the by recursive residuals plot. All residuals lie within the $95 \%$ confidence interval indicating no instability. The CUSUM test for corresponding VAR(3) model shows that parameters estimates 
in the estimated VAR(3) model are stable (statistical results fall within $1 \%$ significance band) suggesting that the parameters estimates in the model are robust. Chow test for structural change or a break point in the model (break-point and forecast tests) indicate no structural break or parameters structural change in the model not rejecting the null of parameters constancy over the full sample period.

\section{F. SVAR model for output, inflation and unemployment}

To best analyse the dynamic properties of the estimated VAR(3) model we use a SVAR model of the form (Lütkepohl 2007):

$$
A y_{t}=A_{1}^{*} y_{t-1}+\ldots+A_{p}^{*} y_{t-p}+B_{0}^{*} x_{t-q}+C^{*} D_{t}+B \varepsilon_{t},
$$

with :

$$
\begin{aligned}
& u_{t}^{\text {Inf }}=a_{12} u_{t}^{U n m}+b_{11} \varepsilon_{t}^{\text {Inf }} \\
& u_{t}^{\text {Unm }}=a_{23} u_{t}^{\text {Out }}+b_{22} \varepsilon_{t}^{\text {Unm }} \\
& u_{t}^{\text {Out }}=a_{31} u_{t}^{\text {Inf }}+b_{33} \varepsilon_{t}^{\text {Out }}
\end{aligned}
$$

\section{Empirical results}

Results obtained from $\operatorname{VAR}(3)$ model estimation show presence of a long-term relationship between unemployment, inflation and output in the United Kingdom. Table 1 summarizes the Granger-causality results for our three-variable VAR and variance decomposition from the recursive VAR ordered (Stock, Watson 2001) as Inflation $\rightarrow$ Unemployment $\rightarrow$ Output. Granger-Causality results with $p$-values from the F-statistics test reveal that inflation account for predicting unemployment, i.e. Granger-cause unemployment at 5\% significance level while unemployment help to predict inflation at $10 \%$ significance level (p-value 0.07 ). Inflation predictive values over output are at $1 \%$ significance level ( $\mathrm{p}$-value 0.00 ) with movement in unemployment causing movement to output (p-value 0.18 ) indicating Granger-noncausality between unemployment and output. Joint significance of unemployment and output shows that both variables are important for predicting future values of inflation ( $p$-value 0.00).

We can check that for all three equations joint significance of unemployment/output $\rightarrow$ inflation, inflation/output $\rightarrow$ unemployment and inflation/unemployment $\rightarrow$ output are have important predictive powers and $1 \%$ significance level proving the hypothesis of the overall Granger-causality between the three variables.

Results of the test for instantaneous causality for inflation/unemployment/output undoubtedly show (at $1 \%$ significance level) the presence of instantaneous causality rejecting the null of no instantaneous causality. Empirical evidence based on instantaneous causality is as expected from the economic theory (short-run interrelation between inflation/unemployment/output). Evidence on Granger-causality for such long-term causality between the variables as the sample period in our model encourages the golden triangle hypothesis with strong statistical significance power. Rarely is expected to find such strong statistical signi- 
Table 1. VAR Descriptive Statistics for (Inf, Unm, Out)

\section{A. Granger-Causality Tests}

Dependent Variables in Regression

\begin{tabular}{ccccc}
\hline Regressor & Inf & Unm & Out & All (Joint significance) \\
\hline Inf & 0.00 & 0.07 & 0.27 & 0.00 \\
\hline Unm & 0.05 & 0.00 & 0.00 & 0.01 \\
\hline Out & 0.01 & 0.18 & 0.00 & 0.00 \\
\hline \multicolumn{5}{c}{ B. Variance Decomposition from the Recursive VAR ordered as Inf $\rightarrow$ Unm $\rightarrow$ Out } \\
\hline \multicolumn{5}{c}{ B.i. Variance Decomposition of Inflation } \\
\cline { 3 - 5 } Forecast Horizon & Forecast Standard Error & Variance Decomposition (percentage points) \\
\hline 1 & 3.33 & 100 & 0.0 & Onm \\
\hline 5 & 4.52 & 88.0 & 4.0 & 0.0 \\
\hline 10 & 4.70 & 87.0 & 5.0 & 8.0 \\
\hline 15 & 4.77 & 85.0 & 6.0 & 8.0 \\
\hline 20 & 4.82 & 84.0 & 8.0 & 8.0 \\
\hline
\end{tabular}

B.i. Variance Decomposition of Unemployment

\begin{tabular}{ccccc}
\hline & & \multicolumn{3}{c}{ Variance Decomposition (percentage points) } \\
\cline { 3 - 5 } Forecast Horizon & Forecast Standard Error & Inf & Unm & Out \\
\hline 1 & 1.62 & 11.0 & 89.0 & 0.0 \\
\hline 5 & 3.01 & 4.0 & 95.0 & 1.0 \\
\hline 10 & 3.58 & 3.0 & 95.0 & 2.0 \\
\hline 15 & 3.93 & 3.0 & 95.0 & 2.0 \\
\hline 20 & 4.18 & 3.0 & 94.0 & 3.0 \\
\hline
\end{tabular}

B.ii. Variance Decomposition of Output

\begin{tabular}{ccccc}
\hline & & \multicolumn{3}{c}{ Variance Decomposition (percentage points) } \\
\cline { 3 - 5 } Forecast Horizon & Forecast Standard Error & Inf & Unm & Out \\
\hline 1 & 2.13 & 1.0 & 29.0 & 70.0 \\
\hline 5 & 2.30 & 2.0 & 32.0 & 66.0 \\
\hline 10 & 2.43 & 2.0 & 38.0 & 60.0 \\
\hline 15 & 2.51 & 2.0 & 41.0 & 56.0 \\
\hline 20 & 2.58 & 2.0 & 44.0 & 54.0 \\
\hline
\end{tabular}

Source: author calculation.

ficance for Granger-causality over a long sample period due to stochastic and deterministic noise in the data process. Significant Granger-causality found and validated in our analysis strongly supports the thesis of the existence of quantitative and long lasting relationship between inflation/unemployment/output in the United Kingdom.

Forecast error decomposition results in Table 1 on the other hand provide limited evidence on the quantitative relationship for inflation/unemployment/output. However, this is not a surprise since the estimated impulse response analysis is a chain causality model inferring 
importance of chosen variable order (timing) for the analysis. For example, if we run an impulse response analysis for the variable order Unemployment $\rightarrow$ Inflation $\rightarrow$ Output we get far more considerable interaction between the variables with less standard error and forecast error of the variables as result of the shock in recursive VAR(3) from 20-40\%. Problem of variable ordering (timing) for the structural analysis and quantitative relationship we explore in the model we intend to resolve by running a SVAR model for inflation/unemployment/output.

Estimated VAR(3) model is presented below with t-statistics in parenthesis (for details see Škare 2012):

$$
\begin{aligned}
& {\left[\begin{array}{l}
\text { Inflation }_{(t)} \\
\text { Unemployment }_{(t)} \\
\text { Output }_{(t)}
\end{array}\right]=\left[\begin{array}{rrr}
0.590 & -0.452 & 0.051 \\
(6.648) & (-2.046) & (0.426) \\
0.092 & 1.048 & -0.039 \\
(2.277) & (10.250) & (-0.545) \\
-0.001 & 0.321 & 0.309 \\
(0.125) & (2.329) & (3.072)
\end{array}\right]\left[\begin{array}{l}
\text { Inflation }_{(t-1)} \\
\text { Unemployment }_{(t-1)} \\
\text { Output }_{(t-1)}
\end{array}\right]+\left[\begin{array}{ccc}
-0.048 & 0.838 & 0.534 \\
(-0.431) & (2.450) & (3.367) \\
-0.069 & -0.278 & -0.049 \\
(-1.395) & (-1.750) & (-0.626) \\
0.003 & -0.234 & -0.069 \\
(0.027) & (-1.037) & (-0.650)
\end{array}\right]\left[\begin{array}{l}
\text { Inflation }_{(t-2)} \\
\text { Unemployment }_{(t-2)} \\
\text { Output }_{(t-2)}
\end{array}\right]+} \\
& {\left[\begin{array}{rrr}
0.149 & -0.419 & -0.161 \\
(1.909) & (-1.711) & (-1.433) \\
0.034 & 0.161 & 0.113 \\
(0.797) & (1.451) & (2.036) \\
0.068 & 0.177 & -0.005 \\
(1.209) & (1.149) & (-0.048)
\end{array}\right]\left[\begin{array}{l}
\text { Inflation }_{(t-3)} \\
\text { Unemployment }_{(t-3)} \\
\text { Output }_{(t-3)}
\end{array}\right]+}
\end{aligned}
$$

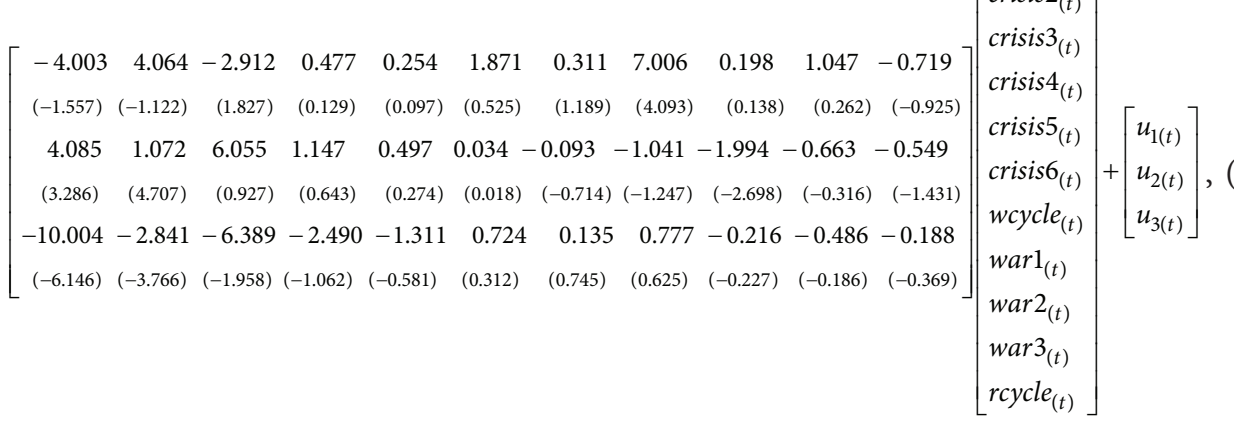

where: Inflation ${ }_{t}$ Unemployment ${ }_{t}$, Output $t_{t}=$ vector of $(k=3)$ observable endogenous variables with three lags; $A_{i}, B_{j}=$ parameter (coefficient) matrices of $(\mathrm{K} \times \mathrm{K})$ dimension and inferred dimension in the case of deterministic vector; $D_{t}=$ deterministic variables vec-

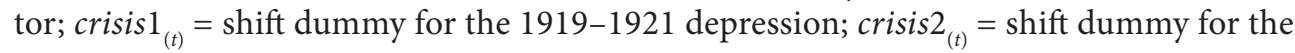
1930-1931 depression; crisis3 $_{(t)}=$ shift dummy for the 1973-1975 oil crises; crisis $_{(t)}=$ shift dummy for the 1980-1982 recession; crisis $5_{(t)}=$ shift dummy for the 1990-1992 recession; crisis $_{(t)}=$ impulse dummy for the 2008/09 crisis; warl $_{(t)}=$ shift dummy for the WWI; $\operatorname{war}_{(t)}=$ shift dummy for the WWII; war3 $_{(t)}=$ shift dummy for the Golf war; wcycle $(t)=$ wage

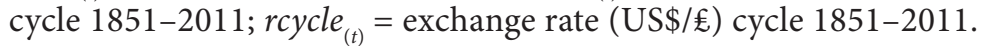


To compensate for a large stochastic trend in stationary data we identified a large vector of deterministic variable to smooth the stochastic noise to the data generation process. Normality test point this was a right approach since normality conditions were largely satisfied except for the Jarque-Berra test and the problem with Kurtosis. Visual inspection of the residuals together with other normality test and practice that normality assumption of $\varepsilon_{t}$ in empirical VAR modelling is difficult to satisfy since we must account for a large number of shocks to the data generation process especially for a large time sample as the one we used. Following Juselius (2009) we conclude that estimates of our VAR(3) model a robust to the deviations from normality assumption particularly taking into account that with compensate the deviations to the data generation process with 11 deterministic variables to cover as much as possible extraordinary shocks occurring in the data. We check the normality assumption also by running the $\operatorname{VAR}(3)$ model with lags $=30$ as suggested by the post-estimation lag order selection (LR). When a lag $20<\mathrm{L}>30$ kurtosis problem in the process was completely removed proving that problem with Jarque-Bera test for normality assumptions of the residual is owed to the stochastic nature of a large data sample and not the problem with VAR estimates robustness.

Estimates of the VAR(3) model give us a rich insight (especially when we estimate the $\operatorname{VAR}(30)$ model) to the long term relationship for inflation/unemployment/output in the United Kingdom during 1851-2011. Negative long-term relationship between inflation and unemployment (Phillips curve) is validated since a statistically significant negative coefficient account for long run relation between the two. From the estimates you can see that the Inflation $_{t}=-0.452$ (Unemployment $\left._{(t-1)}\right)$ indicating that a $1 \%$ increase in unemployment was followed by a -0.452 percentage change drop in inflation (Phillips curve). In the second lag, and this is a very interesting fact, a trade-off between inflation and unemployment dies out resulting in positive relationship during the second year shift in the data. Now a $1 \%$ increase in the unemployment is followed by a 0.838 percentage points increase in the inflation rate. In the third year, once again the trade-off is re-established with a $1 \%$ increase in unemployment leading to a fall in the rate of inflation of -0.419 percentage points (statistically significant a $5 \%)$. Running the VAR(30) model we could observe a clear trade-off pattern between inflation and unemployment in the United Kingdom. Indeed there is a trade-off between inflation and unemployment and Phillips hypothesis is true (with the help of the golden triangle theory), at least when it comes to the economy of the United Kingdom. Negative empirical relationship between unemployment and inflation is validated. Short-term impact multiplier of -0.452 indicate that an increase in unemployment of $1 \%$ will result in inflation fall of -0.452 percentage point (short-run elasticity of inflation is about -0.452 percent). Long-term impact multiplier (sum of all short-run multipliers) equals -0.282 pointing to the straightforward conclusion - a long-term quantitative relation between inflation/unemployment exists and it is a trade-off relation in Philips tradition (1958). Figure 1 display the short and long-run impact multipliers and trade-off between inflation/unemployment/output for a thirty year lag VAR model. 

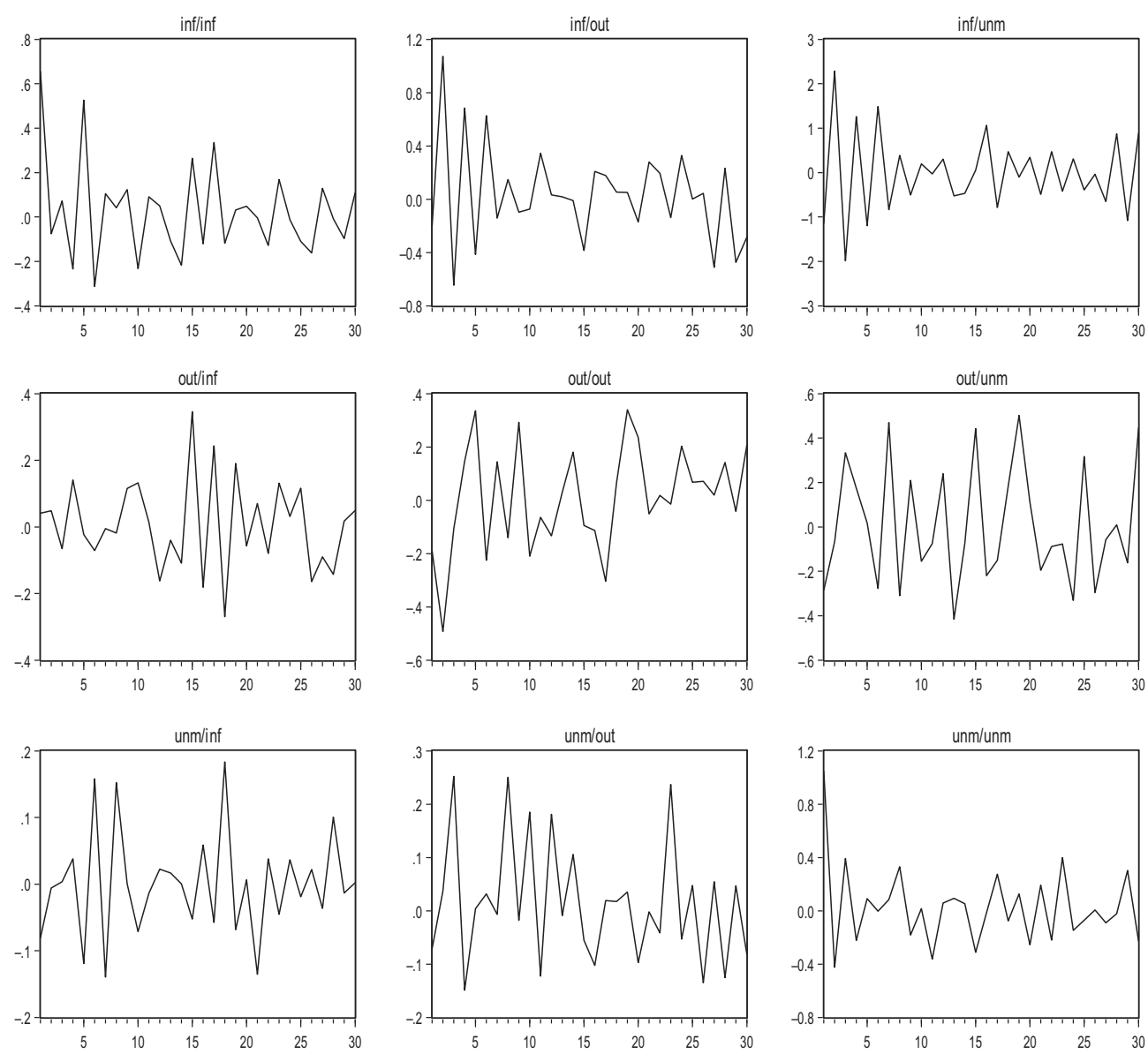

Fig. 1. Estimated short and long run impact multipliers for inflation/unemployment/output (short/long run elasticity of inflation/unemployment/output)

Source: authors calculation.

A clear trade-off pattern and a valid proof for the Phillips hypothesis is visible from the up and down curve displaying a percentage change in inflation due to a $1 \%$ increase in unemployment over the thirty year lag period. In the first year, there is a negative (unit elastic) response of inflation to a $1 \%$ increase in unemployment (Phillips relation). In the second lag (second year) inflation response to a $1 \%$ increase in unemployment is positive and around $2.5 \%$. This is expected and in agreement with the theory since after the fall in inflation in the first year of $1 \%$ unemployment is adjusting to it (see bottom left chart on Figure 1) and so is the output. The third lag is once again in trade-off tradition with an estimated fall in inflation of $2 \%$ since the unemployment adjustment in the second year (together with output adjustment) and so on for the forward lags. Results also shade light on the puzzled Phillips curve (high unemployment and high inflation) experienced after the WWII in the United Kingdom and in 1970s all over the world. The explanation is straightforward from the estimated results. Answer lies in the wage $\rightarrow$ output (productivity) $\rightarrow$ unemployment relationship 
and the golden triangle theory. Top right chart on the Figure 1 clearly display the difference between the short and long run Phillips curve. The trade-off adjusting between inflation and unemployment is going on for over the decade. After 10-12 years of adjustment, Phillips curve takes a short rest (you can see on the figure that impact multipliers shortly die out around 12 years). After that, a new shock, disturbance in the system set the inflation/unemployment/output adjustment mechanism on once again. In Figure 2 we offer the explanation for the unstable Phillips curve in UK for 1945-1977. As claimed by the estimated SVAR model an inflation shock increases unemployment immediately, decrease output in the first year followed by a rise in output after the second year and remaining constant over the year after. Phillips curve adjustment over inflation/unemployment is continuing until the fourth year after which adjustments and inflation/unemployment trade-off continues in the long run but with low intensity. Inflation shock cause a rise in the price level promptly (in the first year) but after the second year inflation shock impact on the general price level is gradually slowing down. Shock in the unemployment has a negative immediate response in inflation with inflation adjusting to the shock in unemployment with a large negative drop (inflation falls consistently). As in the case of the inflation shock, trade-off between unemployment/ inflation is consistent and significant until the fourth year with the trade-off slowly dying out in the long run.
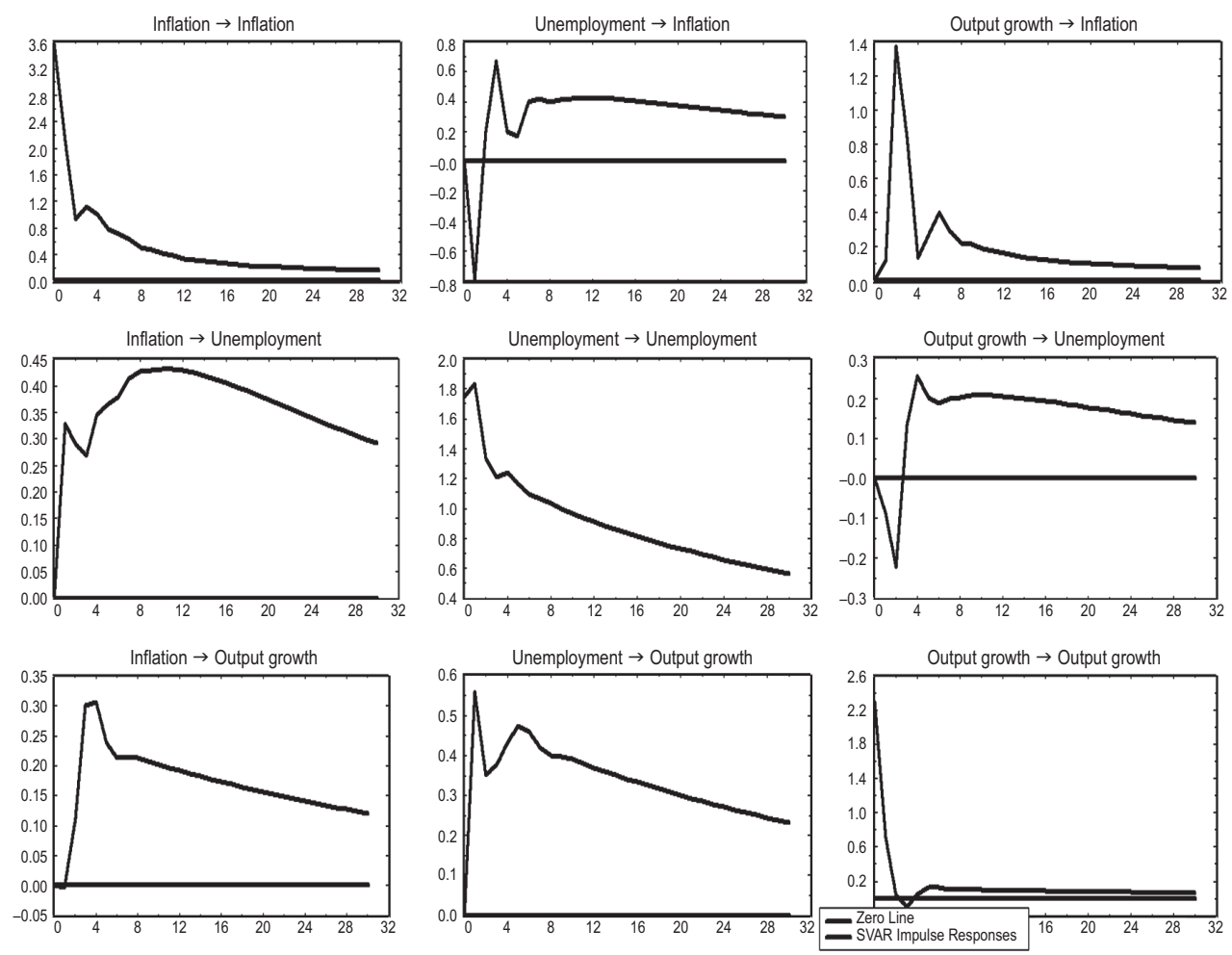

Fig. 2. SVAR impulse response of inflation/unemployment/output Source: author calculation. 
The results prove our hypothesis the Phillips curve is not vertical in the long run but oscillating (on small scale) about the natural unemployment rate (or in the golden triangle terminology about the golden unemployment node). Unemployment shock points to the existence of the hysteresis in unemployment (Song 1998). Changes in the actual rate of unemployment have a strong impact on the natural unemployment rate over the period of 30 years with the natural rate falling when actual rate is below natural and contrary. Shock in the unemployment causes immediate response in output adjusting to the new golden equilibrium. In theory, negative effects of shock in unemployment are expected on output. This is true if we look for a unidirectional link between unemployment and output. Such a unidirectional relation does not exist under the golden triangle assumptions. Final effect of the shock in unemployment is dependent on the simultaneous changes going on between inflation/unemployment/output. Economy is adjusting to the shocks through the changes in the golden triangle nodes and if it is successful, i.e. policy makers set up measure appropriate to the moment, beginning shock in unemployment could result in output increase over time if policy makers and golden triangle model are in synchrony. If this is not the case, when policy makers ignores the quantitative relationship that exists between inflation/unemployment/output they will certainly act upon economy with inappropriate and wrong set of instruments and policies worsening the situation in the economy. This is in fact what happened in the United Kingdom during 1945-1977. Policy makers completely ignored the quantitative relations that exists (and that we proved here) between inflation/unemployment/ output (and still do ignore) that a demand/supply shocks, together with oil shock at the time could not be constrained by the Phillips curve mechanism alone resulting in unstable Phillips curve for the time. There is nothing wrong with the Phillips curve at the time but all is wrong with the macroeconomic policy implemented and that is what triggered the chain of events in the United Kingdom causing unstable Phillips curve appearance. The productivity/wage gap worsened the situation at the time encouraging unstable Phillips curve appearance. When the productivity/wage gap diminished (around 1980) Phillips curve returned to its more traditional form although with not so strong negative relationship between inflation/unemployment as before the WWII. Further adjustments in the golden triangle model are needed to return to the traditional Phillips curve form at present. Supply shock on the price level is evident and long lasting (twelve year cycle). Shock in the production (output) levels drives production level up with shock effects after a two year cycle sharply falling to zero. Shock in the production level register positive temporary effect on future output level. Output growth is followed by immediate drop in the unemployment rate corrected with prompt increase in the price level (Phillips' curve theory). To asses relative importance of individual shock in inflation/unemployment/ output we measure the forecast error variance decomposition (Fig. 3).

Shocks in the price level are dominant source for Inflation in the United Kingdom with unemployment and output shocks explaining about $30 \%$ of the variance in inflation. Variance in unemployment however is significantly jointly explained by shocks in output and inflation (about $40 \%$ of the variance in unemployment) with $60 \%$ variance in unemployment explained by the shocks in the unemployment. Output growth is important source factor and determinant for the output growth in the long run (about 70\%). Considerable joint significance of unemployment and inflation in output variance in the long run is about $30 \%$ suggesting important interaction level between the variables. 
Forecost error of 'Inflation'

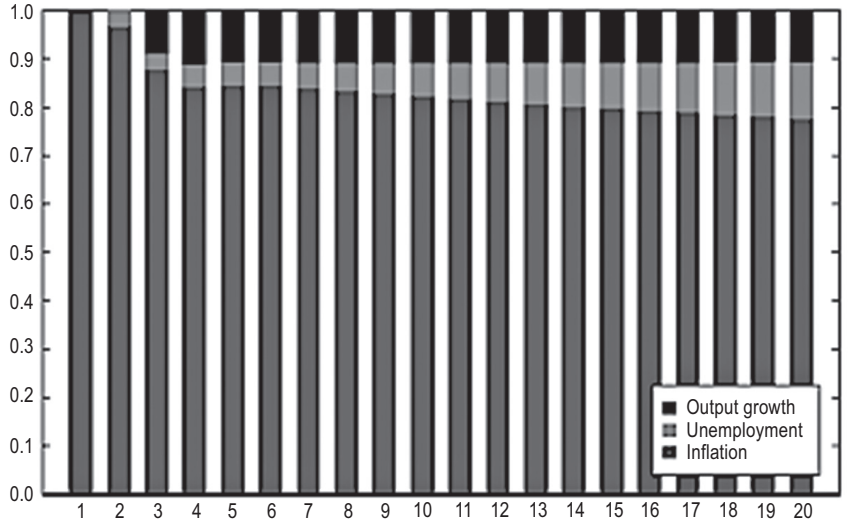

Forecast error of 'Unemployment'

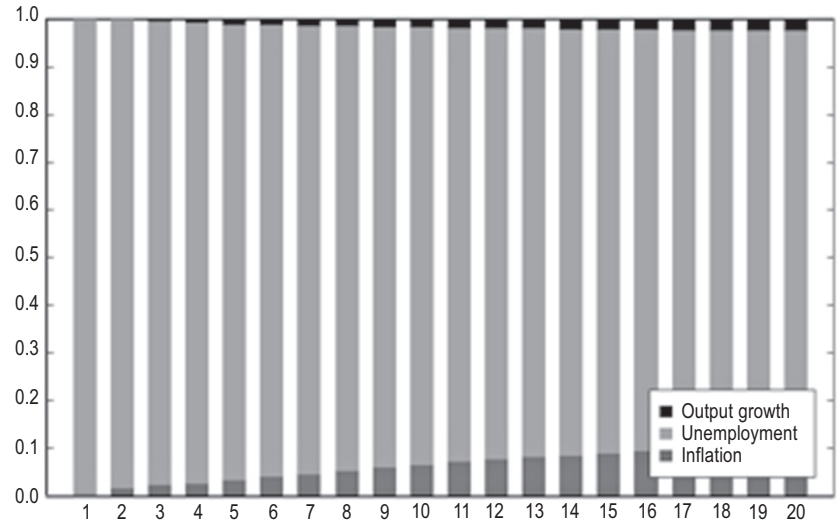

Forecast error of 'Output growth'

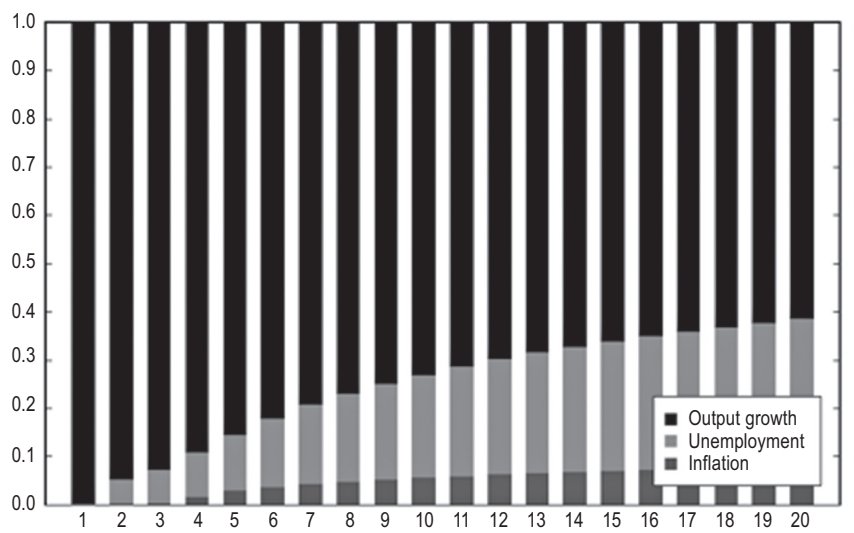

Fig. 3. Forecast error variance decomposition of inflation/unemployment/output Source: author calculation. 


\section{Conclusions and future research}

Study results point to several important conclusions. First one is related to the traditional Phillips curve theory. Validated results in the paper prove the existence of the Phillips curve in the United Kingdom for the period 1851-2011. Estimated long term impact multiplier (long run inflation elasticity) for inflation/unemployment is negative with a value of -0.282 vindicating the negative empirical relationship between inflation and unemployment in the United Kingdom 1851-2011. Phillips curve does exist (at least for the UK economy). Second important conclusion inferred from the golden triangle theory concerns the natural rate of unemployment theory. Economies do tend toward a specific unemployment rate but this rate isn't to be considered natural or fixed over time. It is just one of three nodes of the golden triangle model ensuring country's internal macroeconomic equilibrium at certain point in time. This golden node or to say equilibrium unemployment rate is a dynamic phenomenon, constantly changing over time so can't be fixed to 5 or $6 \%$ as the theory of natural unemployment rate suggests. Third conclusion to which the results point to is that Phillips curve is not vertical in the long run because actual rate do not equal the theoretical natural unemployment rate. Results infer that the natural unemployment rate (our golden node) is constantly changing over time there cannot be a vertical Phillips curve in the long run. Estimates of the impact multipliers substantiate this conclusion since inflation/unemployment adjustment (trade-off) is going on over the period of 30 lags, multipliers not dies out as the theory of natural unemployment rate demand. Inflation/unemployment long term impact multipliers in Figure 2 validate this statement. Change in the unemployment rate affects the inflation rate continuously. Also cyclicality in the impact multipliers trend can be noticed. After 12 years, unemployment impact on inflation slowly settles down (the same pattern repeats after second twelve years period at lag $=24$ ) but never dies out. Trade-off adjustment between inflation/unemployment in the UK economy is ever lasting and implies no vertical Phillips curve in the long run.

Fourth conclusion we empirically asses is that there is hysteresis in unemployment. Impact multiplier for unemployment/unemployment (long run elasticity for unemployment) with value 0.8279 so natural rate unemployment dynamics is significantly affected by the change in the actual rate of unemployment. It is the dynamics of the actual unemployment rate that alters the natural unemployment rate within the golden triangle model framework (together with output and inflation dynamics).

Fifth conclusion is partially based on the Friedman-Phelps theory. Long run impact multipliers for inflation/output (0.93) and unemployment/output (0.21), i.e. long run elasticity coefficients show that Phillips curve is in fact sensitive to the supply and wage shocks. Simultaneous shocks to expected inflation supported by wage shocks and changes in the golden triangle nodes that actual shifts the Phillips curve. It is the simultaneous relationship between inflation/unemployment/output that guides the shifts in the Phillips curve. Exploring why a Phillips curve during 1945-1977 exhibits no systematic relationship in Phillips tradition is our sixth conclusion. Instability in the Phillips curve in the United Kingdom after WWII was caused by the disequilibrium in the golden triangle. Particularly, adverse supply shocks had driven by the large growth in the unit wage costs over output per worker, oil crises, demand 
shocks and monetary validation that caused large, incontrollable changes to inflation and unemployment trend. Such large shocks could not be self-corrected just by a Phillips curve mechanism. This, however, does not imply that a negative systematic relationship between inflation and unemployment did not exist in the UK economy at that time. It did, but policy makers cannot count just on the Phillips curve correction mechanism itself to resolve large instability shocks present at that time. This brings us to our last conclusion. Systematic quantitative relationship between inflation/unemployment/output exists for the UK economy as supposed by Phillips. Our results prove that the golden triangle model exists for the UK economy validating as such systematic quantitative relationship for inflation/unemployment/ output. Policy makers cannot guarantee just by using the Phillips curve mechanism to maintain targeted levels of inflation or unemployment. Golden triangle model offers to policy makers a set of choices to choose from when targeting main macroeconomic goals. Failure to do so and not account for quantitative and systematic relationship that exists between inflation/ unemployment/output in the UK economy results in improper policy measures or inappropriate in magnitude and timing as was the case in the United Kingdom after the WWII and later on in 70's, 80's, 90's causing large distress to the UK economy. This is our modest attempt to the development of the golden triangle theory and research on the employment/ inflation/output quantitative relationship as supposed by Phillips long time ago hoping to encourage future research on the subject.

\section{References}

Acemoglu, D.; Scot, A. S. 1994. Asymmetries in the cyclical behaviour of UK labour markets, Economic Journal 104(427): 1303-1323. http://dx.doi.org/10.2307/2235450

Adams, C.; Coe, D. 1989. A systems approach to estimating the natural rate of unemployment and potential output for the United States, IMF Working Paper. 89 p.

Aguiar, A.; Martins, M. M. F. 2005. Testing the significance and the nonlinearity of the Phillips trade-off in the Euro area, Empirical Economics 30(3): 665-691. http://dx.doi.org/10.1007/s00181-005-0250-z

Akaike, H. 1969. Fitting autoregressive models for prediction, Annals of the Institute for Statistical Mathematics 21(1): 243-247. http://dx.doi.org/10.1007/BF02532251

Akaike, H. 1971. Autoregressive model fitting for control, Annals of the Institute for Statistical Mathematics 23(2): 163-180. http://dx.doi.org/10.1007/978-1-4612-1694-0_12

Altig, D.; Fitzgerald, T.; Rupert, P. 1997. Okun's law revisited: should we worry about low unemployment, Economic Commentary 15: 1-4.

Apergis, N.; Rezitis, A. 2003. An examination of Okun's law: evidence from regional areas in Greece, Applied Economics 35(10): 1147-1151. http://dx.doi.org/10.1080/0003684032000066787

Attfield, C. L. F.; Silverstone, B. 1998. Okun's law, cointegration and gap variables, Journal of Macroeconomics 20(3): 625-637. http://dx.doi.org/10.1016/S0164-0704(98)00076-7

Bierens, H. J. 2007. Econometric analysis of linearized singular dynamic stochastic general equilibrium models, Journal of Econometrics 136(2): 595-627. http://dx.doi.org/10.1016/j.jeconom.2005.11.008

Bodman, P. 1998. Asymmetry and duration dependence in Australian GDP and unemployment, The Economic Record 74(227): 399-411. http://dx.doi.org/10.1111/j.1475-4932.1998.tb01934.x

Boyer, G. R.; Hatton, T. J. 2001. New estimates of British unemployment, 1870-1913, Journal of Economic History 62(3): 643-675. 
Bratu, M. 2012. The reduction of uncertainty in making decisions by evaluating the macroeconomic forecasts performance in Romania, Economic Research - Ekonomska Istraživanja 25(2): 239-262.

Breitung, J. 2000. The local power of some unit root tests for panel data, in Baltagi, B. (Ed.). Advances in Econometrics. Vol. 15: Nonstationary Panels, Panel Cointegration, and Dynamic Panels. Amsterdam: JAI Press, 161-178.

Breusch, T. S. 1979. Testing for autocorrelation in dynamic linear models, Australian Economic Papers 17(31): 334-355. http://dx.doi.org/10.1111/j.1467-8454.1978.tb00635.x

Brunner, A. D. 1997. On the dynamic properties of asymmetric models of real GNP, Review of Economics and Statistics 79(2): 321-326. http://dx.doi.org/10.1162/003465397556674

Campbell, J. R.; Fisher, J. D. M. 2000. Aggregate employment fluctuations with microeconomic asymmetries, American Economic Review 90(5): 1323-1345. http://dx.doi.org/10.1257/aer.90.5.1323

Campbell, J. Y.; Mankiw, N. G. 1987. Are output fluctuations transitory?, The Quarterly Journal of Economics 102(4): 857-880. http://dx.doi.org/10.2307/1884285

Choi, I. 2001. Unit root tests for panel data, Journal of International Money and Finance 20(2): 249-272. http://dx.doi.org/10.1016/S0261-5606(00)00048-6

Cochrane, J. 1988. How big is the random walk in GNP?, Journal of Political Economy 96(5): 893-920. http://dx.doi.org/10.1086/261569

Courtney, H. G. 1991. The Beveridge curve and Okun's law: a re-examination of fundamental relationships in the United States: $\mathrm{PhD}$ thesis. Massachusetts Institute of Technology.

Cuaresma, J. C. 2003. Okun's law revisited, Oxford Bulletin of Economics and Statistics 65(4): 439-451. http://dx.doi.org/10.1111/1468-0084.t01-1-00056

Davenport, P. 1982. Technical change and unemployment, Journal of Post Keynesian Economics 1: 34-50.

Evans, G. 1989a. Output and employment dynamics in the United States: 1950-1985, Journal of Applied Econometrics 4(3): 213-237. http://dx.doi.org/10.1002/jae.3950040302

Evans, G. 1989b. A measure of the U.S. output gap, Economic Letters 29(4): 285-289. http://dx.doi.org/10.1016/0165-1765(89)90202-4

Friedman, M. 1968. The role of monetary policy: presidential address to AEA, American Economic Review LVIII(1): 1-17.

Godfrey, L. G. 1978. Testing against general autoregressive and moving average error models when the regression include lagged dependent variables, Econometrica 46(6): 1293-1302. http://dx.doi.org/10.2307/1913829

Gordon, R. J. 1990. The Phillips curve now and then, NBER Working Paper No. 3393, 1-20.

Granger, C. W. J.; Joyeux, R. 1980. An introduction to long-memory time series models and fractional differencing, Journal of Time Series Analysis 1(1): 15-30. http://dx.doi.org/10.1111/j.1467-9892.1980.tb00297.x

Hadri, K. 2000. Testing for stationarity in heterogeneous panel data, Econometric Journal 3(2): 148-161. http://dx.doi.org/10.1111/1368-423X.00043

Hicks, J.; Grahame, A. 1999. A century of change: trends in UK statistics since 1900, House of Commons Research Paper No. 99/111, 1-34.

Ho, M. S.; Sorensen, B. E. 1996. Finding cointegration rank in high dimensional systems using the Johansen test: an illustration using data based Monte Carlo simulations, Review of Economics and Statistics 78(4): 726-732. http://dx.doi.org/10.2307/2109959

Hodrick, R. J.; Prescott, E. C. 1997. Postwar U.S. business cycles: an empirical investigation, Journal of Money, Credit and Banking 29(1): 1-16. http://dx.doi.org/10.2307/2953682

Hooker, M. 2002. Are oil shocks inflationary? Asymetric and nonlinear specifications versus changes in regime, Journal of Money, Credit and Banking 34(2): 540-561. http://dx.doi.org/10.1353/mcb.2002.0041 
Hsing, Y. 2011. Macroeconomic variables and the stock market: the case of Croatia, Economic Rersearch Ekonomska Istraživanja 24(4): 41-50.

Im, K. S.; Pesaran, M. H.; Shin, Y. 2003. Testing for unit roots in heterogeneous panels, Journal of Econometrics 115(1): 53-74. http://dx.doi.org/10.1016/S0304-4076(03)00092-7

Jovanovski, T.; Muric, M. 2011. The phenomenon of lag in application of the measures of monetary policy, Economic Research - Ekonomska Istraživanja 24(2): 10 p.

Juselius, K. 2009. The cointegrated VAR model: methodology and applications. Oxford: Oxford University Press. 480 p.

Kaldor, N. 1992. The economics and politics of capitalism as a dynamic system. Oxford: Oxford University Press. 402 p.

Keynes, J. M. 1936. The general theory of employment, interest and money. London: Macmillan. 403 p.

Levin, A.; Lin, C. F.; Chu, C. J. 2002. Unit root tests in panel data: asymptotic and finite-sample properties, Journal of Econometrics 108(1): 1-24. http://dx.doi.org/10.1016/S0304-4076(01)00098-7

Lee, J. 2000. The robustness of Okun's law: evidence from OECD countries, Journal of Macroeconomics 22(2): 331-356. http://dx.doi.org/10.1016/S0164-0704(00)00135-X

Lorenzoni, G. 2010. A theory of demand shocks, American Economic Review 99(5): 2050-2084. http://dx.doi.org/10.1257/aer.99.5.2050

Lütkepohl, H. 2007. New introduction to multiple time series analysis. New York: Springer Verlag. 764 p.

Maddala, G. S.; Shaowen, W. 1999. A comparative study of unit root tests with panel data and a new simple test, Oxford Bulletin of Economics and Statistics 61(S1): 631-652. http://dx.doi.org/10.1111/1468-0084.0610s1631

Measuring Worth. 2012 [online], [cited 17 June 2012]. Available from Internet: http://www.measuringworth.com

Mitchell, B. R. 1988. British historical statistics. Cambridge: Cambridge University Press. 886 p.

Nakon, A.; Pescatori, A. 2010. Oil and the great moderation, The Economic Journal 120(543): 131-156. http://dx.doi.org/10.1111/j.1468-0297.2009.02302.x

Nickell, S. 1998. Unemployment: questions and some answers, The Economic Journal 108(448): 802-816. http://dx.doi.org/10.1111/1468-0297.00316

Okun, A. 1980. Postwar macroeconomic performance, in Feldstein, M. (Ed.). The American Economy in Transition. Chicago: University of Chicago Press, 162-170.

Okun, A. 1981. Prices and quantities: a macroeconomic analysis. Washington: The Brookings Institution. $367 \mathrm{p}$.

Palley, T. 1993. Okun's law and the asymmetric and changing cyclical behaviour of the USA economy, International Review of Applied Economics 7(2): 144-162. http://dx.doi.org/10.1080/758530144

Phelps, E. S. 1967. Philips curves, expectations of inflation and optimal unemployment over time, Economica 34(135): 254-281. http://dx.doi.org/10.2307/2552025

Phelps, E. S.; Zoega, G. 1998. Natural rate theory and OECD unemplyoment, The Economic Journal 108(448): 782-801. http://dx.doi.org/10.1111/1468-0297.00315

Phillips, A. W. 1958. The relation between unemployment and the rate of change of money wage rates in the United Kingdom, 1861-1957, Economica 25(100): 283-299. http://dx.doi.org/10.2307/2550759

Phillips, A. W. 1962. Employment, inflation and growth, Economica 29(113): 1-16. http://dx.doi.org/10.1111/j.1468-0335.1962.tb00001.x

Reno, E. 2010. Statistical yearbook of the League of Nations. Northwestern University Library. Chicago, 1-875.

Rothman, P. 1991. Further evidence on the asymmetric behaviour of unemployment rates over the business cycle, Journal of Macroeconomics 13(2): 291-298. http://dx.doi.org/10.1016/0164-0704(91)90057-2 
Samuelson, P. 2008. Thoughts about the Phillips curve, FRBB Conference Series 53, 9-11 June, 2008, Chatham, Massachusetts.

Sögner, L.; Stiassny, A. 2002. An analysis on the structural stability of Okun's law - a cross-country study, Applied Economics 34(14): 1775-1787. http://dx.doi.org/10.1080/00036840210124180

Song, F. M. 1998. Hysteresis in unemployment: evidence from OECD countries, Quarterly Review of Economics and Finance 38(2): 181-192.

Song, M.; Wang, S.; Wang, Z. 2012. A new method for measuring the economic convergence and its application on central China provinces, Economic Research - Ekonomska Istraživanja 25(4): 925-936.

Stock, H. J.; Watson, M. W. 2001. Vector autoregression, The Journal of Economic Perspectives 15(4): 101-115. http://dx.doi.org/10.1257/jep.15.4.101

Stubelj, I.; Dolenc, P. 2010. Fiscal sustainability of EU member states in the context of current financial crisis, Economic Research - Ekonomska Istraživanja 23(4): 37-62.

Škare, M. 2010. Can there be a 'golden triangle' of internal equilibrium, Journal of Policy Modeling 32(4): 562-573. http://dx.doi.org/10.1016/j.jpolmod.2010.05.005

Škare, M. 2012. Discovering the inflation true nature, in Hasanov, M. (Ed.). Inflation, Deflation and Disinflation. New York: NOVA Publisher, 1-63.

Thirlwall, A. P. 1969. Unemployment compensation as an automatic stabiliser, Bulletin of the Oxford University Institute of Economics \& Statistics, 23-37.

Thirlwall, A.; Norman, J. I. 1970. Okun's law and the natural rate of growth: reply, Southern Economic Journal 37(2): 232-234. http://dx.doi.org/10.2307/1056140

Thurow, L.; Taylor, L. 1966. The interation between the actual and potential rates of growth, The Review of Economics and Statistics 48(4): 351-360. http://dx.doi.org/10.2307/1924613

Tobin, J. 1996. Essays in economics: national and international. Vol. 4. Hong Kong: MIT Press. 807 p.

Vercelli, A. 2005. Granger causality and rational expectations: an uneasy marriage, in Conference Proceedings, Bologna Conference on Causality, Probability and Rationality, May, 2005, Bologna, Italy.

Virén, M. 2001. The Okun curve is non-linear, Economics Letters 70(2): 253-257. http://dx.doi.org/10.1016/S0165-1765(00)00370-0

Weber, C. E. 1995. Cyclical output, cyclical unemployment, and Okun's coefficient: a new approach, Journal of Applied Econometrics 10(4): 433-445. http://dx.doi.org/10.1002/jae.3950100407

Marinko ŠKARE. Professor of Economics, Editor in Chief of the Economic Research Journal, Member of Editorial Board of several international journals, Faculty of Economics and Tourism "Dr. Mijo Mirković" in Pula, Juraj Dobrila University of Pula. He served as Assistant Dean for Education, Faculty of Economics and Tourism, Pula; Assistant Dean for International Cooperation, Faculty of Economics and Tourism, Pula, Main and Team Researcher on several scientific projects; Former Dean of the Faculty of Economics \& Tourism, Pula and Former Vice President for International Cooperation, Juraj Dobrila University of Pula. He is a member of the American Economic Association, Royal Economic Society, Economic History Association, Economic History Society, and Association for Comparative Economic Studies. He has published several books and a large number of scientific papers on the subject of economic growth, welfare economics and poverty, human capital, economics in transition, economic philosophy and monetary economics. 